\title{
ANALISIS DAN PERANCANGAN SISTEM INFORMASI PADA COFFEE SHOP SONGOT BERBASIS CLIENT SERVER
}

\author{
Alfian Bahardiansyah, Riki Yulianto, Nurlita Novitasari \\ Alfiandian52@gmail.com \\ Ryulianto451@gmail.com \\ Litasari36@gmail.com
}

\begin{abstract}
:
The purpose of this study is the author wants to know how to analyze and design information systems at Songot coffee shop. Benefits for the Company, namely the existence of this management information system is expected to be able to streamline and streamline data processing in the staffing section and the ordering section. In addition, the integration of company data is also expected to speed up the process of presenting information to be used as reference material for company decision making. The research method uses a structured approach, a piecemeal approach against a systems approach, a bottom-up approach against a top-down approach, a holistic system approach versus a system approach. modular, long jump approach versus growing approach. Object-oriented approach, Web-based approach. As a result, the system is designed to include Sales, employee attendance and Payroll. And compiled with several tables that have passed the normalization process. The system will produce several required reports including sales reports, employee reports, purchasing reports and customer \& supplier reports.
\end{abstract}

Keyword : Information System, Information system of coffeeshop, Information System of Payroll, Purchases, and Sales. 


\begin{abstract}
abstrak :
Tujuan penelitian ini adalah penulis ingin mengetauhi Bagaimana cara analisis dan perancangan sistem informasi pada coffee shop Songot. Manfaat untuk Perusahaan yaitu Dengan adanya sistem informasi manajemen ini diharapkan dapat mengefektifkan dan mengefesiensikan penggolahan data di bagian kepegawaian dan bagian pemesanan. Selain itu pengintegrasian data - data perusahaan diharapkan juga dapat mempercepat proses penyajian informasi untuk menjadi bahan acuan pengambialan keputusan perusahaan.Metode penelitian dengan melakukan Pendekatan Terstuktur, Pendekatan sepotong melawan pendekatan system, Pendekatan bawah-naik melawan pendekatan atas-turun, Pendekatan system menyeluruh lawan pendekatan moduler, Pendekatan lompatan jauh lawan pendekatan berkembang. Pendekatan berorientasi objek, Pendekatan berbasis web. Hasilnya, Sistem dirancang meliputi Penjualan, absensi karyawan dan Penggajian. Dan disusun dengan beberapa table yang sudah melewati proses normalisasi. System nantinya akan menghasilkan beberapa laporan yang dibutuhkan diantaranya laporan penjualan, laporan karyawan, laporan pembelian dan laporan pelanggan \& pemasok.
\end{abstract}

Kata Kunci : Sistem Informasi, Sistem Informasi Kedai Kopi, Sistem Informasi Penggajian, Pembelian, dan Penjualan.

\title{
Pendahuluan
}

\section{Latar belakang}

Komputer merupakan salah satu alat untuk memproses data menjadi informasi yang berguna oleh karena itu, untuk memproses data menjadi informasi komputer memerlukan suatu software sistem informasi, Dengan menggunakan sistem informasi tersebut maka data dapat diproses menjadi informasi yang berguna baik untuk sekarang maupun akan datang.

Warung kopi atau cafe sekarang sudah banyak dijumpai dari kota besar sampai kota yang kecil, seiring berkembang, warung kopi menjadi tempat yang sering dicari atau dibutuhkan untuk minum kopi,kumpul bersama teman-teman. Sekarang banyak pengusaha café / warung kopi yang melakukan inovasi serta pembaharuan dalam mendayagunakan dan mengoptimalkan peranan dari teknologi informasi.

Sebuah sistem yang baik dapat meningkatkan kualitas dan kinerja sebuah organisasi atau instansi, kebutuhan akan informasi semakin meningkat, oleh karena itu keperluan sejumlah informasi yang cukup luas mutlak diperlukan untuk mengambil keputusan yang efektif dan 
efisien. Sehingga setiap manusia diharapkan mampu memanfaatkan kemajuan teknologi untuk meningkatkan kemampuan.

Oleh sebab itu diperlukan langkah kongkret yang perlu ditingkatkan pada Coffee Shop SONGOT agar mampu bersaing didunia bisnis dan usaha diantaranya melalui teknologi informasi seperti aplikasi database pada penjualan dan pengolahan data karyawan yang nantinya dapat mempermudah dalam pengembangan sistem usaha dengan lebih baik. Namun, fakta yang terjadi pada Coffee Shop SONGOT belum mengoptimalkan teknologi informasi terutama pada sistem penjualan, absensi, pengajian. Sistem informasi yang diterapkan masih bersifat manual, yaitu secara tertulis. Untuk rumusan masalahnya, Bagaimana cara analisis dan perancangan sistem informasi pada coffee shop Songot dan Tujuan penelitian ini adalah penulis ingin mengetauhi Bagaimana cara analisis dan perancangan sistem informasi pada coffeeshop Songot serta untuk manfaat penelitian, Dengan adanya sistem informasi manajemen ini diharapkan dapat mengefektifkan dan mengefesiensikan penggolahan data di bagian kepegawaian dan bagian pemesanan. Selain itu pengintegrasian data - data perusahaan diharapkan juga dapat mempercepat proses penyajian informasi untuk menjadi bahan acuan pengambialan keputusan perusahaan.

\section{Landasan Teori}

\section{Konsep Sistem Informasi}

\section{Sistem}

Pada dasarnya kata sistem berasal dari kata yunani "sytema" yang berarti kesatuan, yakni keseluruhan dari bagian - bagian yang mempunyai hubungan satu sama lain. Untuk mendefinisikan sistem terdapat dua pendekatan, yaitu yang menekankan pada prosedurnya dan yang menekankan pada komponen atau elemennya. Pendekatan sistem yang menekankan pada prosedurnya mendefinisikan sistem sebagai suatu jaringan kerja dari prosedur-prosedur yang saling berhubungan, berkumpul bersama-sama untuk melakukan suatu kegiatan atau untuk menyelesaikan suatu sasaran yang tertentu. Prosedur adalah suatu uruturutan operasi klerikal (tulis menulis) biasanya melibatkan beberapa orang di dalam satu atau lebih departemen, yang diterapkan untuk menjamin penanganan yang seragam dari transaksi- 
transaksi bisnis yang terjadi. Berbeda dengan sistem yang menekankan pada prosedurnya, sistem yang menekankan pada komponen atau elemennya mendefinisikan sistem sebagai kumpulan dari elemen-elemen yang berinteraksi untuk mencapai suatu tujuan tertentu. Pendekatan sistem yang merupakan kumpulan elemen- elemen atau komponen- komponen atau subsistem- subsistem merupakan definisi yang lebih luas. Pendekatan sistem yang menekankan pada komponen akan lebih di dalam mempelajari suatu sistem untuk tujuan analisis dan perancangan suatu sistem

\section{Menurut para ahli:}

Sistem menurut (Hall, 1956) adalah sekumpulan objek, yang mencakup hubungan diantara objek tersebut serta hubungan antara sifat yang mereka miliki.

Menurut (Ackoff, 1971) sistem terdiri dari empat elemen yaitu, objek, atribut, hubungan internal dan lingkungan. Objek dapat berupa benda fisik, abstrak, ataupun keduanya sekaligus, tergantung kepada sifat sistem tersebut. Atribut, yang menentukan kualitas atau sifat kepemilikan sistem dan objeknya. Hubunganinternal, keterkaitan objek objek didalam sistem. Contohnya Nomor Induk Mahasiswa berhubungan dengan jenis buku yang dipinjam. Lingkungan, berkaitan dengan dimana sistem itu ditempatkan, contohnya yaitu sistem perpustakaan yang dibuat digunakan di Jurusan Teknik Elektro.

Syarat - syarat sesuatu disebut sistem menurut (H M Jogiyanto, 2005) yaitu, sistem dibentuk untuk menyelesaikan masalah, elemen sistem mempunyai perencanaan yang sudah ditetapkan, adanya hubungan antara elemen sistem, proses lebih diutamakan dari pada element sistem.

Menurut (Kadir, 2002) bahwa "Sistem adalah sekumpulan elemen yang saling terkait atau terpadu yang dimaksudkan untuk mencapai suatu tujuan”.

Menurut (Sutabri, 2012)bahwa "Sistem adalah suatu kumpulan atau himpunan dari suatu unsur, komponen, atau variabel yang terorganisasi, saling berinteraksi, saling tergantung satu sama lain dan terpadu".

Menurut (Fathansyah, 2015) bahwa "Sistem adalah sebuah tatanan (keterpaduan) yang terdiri atas sejumlah komponen fungsional (dengan satuan fungsi dan tugas khusus) yang saling berhubungan dan secara bersama-sama bertujuan untuk memenuhi suatu proses tertentu".

Dari beberapa pengertian di atas penulis dapat menyimpulkan bahwa sistem merupakan sekumpulan elemen, himpunan dari suatu unsur, komponen fungsional yang 
saling berhubungan dan berinteraksi satu sama lain untuk mencapai tujuan yang diharapkan.

Pengertian dan definisi sistem yang telah dijelaskan diatas berbeda - beda namun kita dapat mengambil beberapa bersamaan umum, yaitu sistem harus memliki elemen, lingkungan dan hubungan antar keduannya. Sistem Informasi Inventarisasi Buku Perpustakaan Jurusan Teknik Elektro Universitas NegeriSemarang nantinya akan terdiri dari elemen - elemen yang saling berhubungan sehingga akan menghasilkan sistem yang baik untuk memberikan informasi yang dibutuhkan.

\section{Informasi}

Pengertian informasi menurut (McLeod Jr, 2001) adalah data yang telah diolah menjadi bentuk yang memiliki arti bagi si penerima dan bermanfaat bagi pengambilan keputusan saat ini atau mendatang.

Menurut (Sutabri, 2012) data yang diolah untuk menghasilkan informasi menggunakan suatu model proses tertentu. Data yang diolah melalui suatu model menjadi informasi, penerima kemudian menerima informasi tersebut, membuat suatu keputusan dan melakukan tindakan, yang berarti menghasilkan suatu tindakan yang lain yang akan membuat sejumlah data kembali. Data tersebut akan ditangkap sebagai input, diproses kembali lewat suatu model dan seterusnya membentuk suatu siklus.

\section{Sistem Informasi}

Sistem informasi adalah suatu sistem di dalam suatu organisasi yang mempertemukan kebutuhan pengolahan transaksi harian yang mendukung fungsi operasi organisasi yang bersifat manajerial dengan kegiatan strategi dari suatu organisasi untuk dapat menyediakan kepada pihak luar tertentu dengan laporan- laporan yang diperlukan (Sutarbi, 2005)

Sistem informasi yang dikemukakan oleh (Romney et al., 2000) dalam International Journal of Economics and Finance adalah sebuah sistem informasi adalah cara mengorganisir untuk mengumpulkan, mencatat, dan pengolahan data dan menyimpan, mengelola, mengendalikan, dan pelaporan informasi sehingga organisasi dapat mencapai tujuan dan sasaran.

Sistem informasi merupakan kesatuan elemen-elemen yang saling berinteraksi secara sistematis dan teratur untuk menciptakan dan membentuk aliran informasi yang akan mendukung pembuatan keputusan dan melakukan kontrol terhadap jalannya perusahaan (Watung \& Sinsuw, 2014). 
Dari beberapa definisi tentang sistem informasi dapat disimpulkan bahwa sistem informasi adalah suatu sistem yang dirancang untuk menyediakan suatu informasi yang saling berinteraksi secara sistematis dan teratur.

Secara konseptual siklus pengembangan sebuah sistem informasi adalah sbb:

Analisis Sistem: menganalisis dan mendefinisikan masalah dan kemungkinan solusinya untuk sistem informasi dan proses organisasi.

Perancangan Sistem: merancang output, input, struktur file, program, prosedur, perangkat keras dan perangkat lunak yang diperlukan untuk mendukung sistem informasi

Pembangunan dan Testing Sistem: membangun perangkat lunak yang diperlukan untuk mendukung sistem dan melakukan testing secara akurat. Melakukan instalasi dan testing terhadap perangkat keras dan mengoperasikan perangkat lunak

Implementasi Sistem: beralih dari sistem lama ke sistem baru, melakukan pelatihan dan panduan seperlunya.

Operasi dan Perawatan: mendukung operasi sistem informasi dan melakukan perubahan atau tambahan fasilitas.

Evaluasi Sistem: mengevaluasi sejauih mana sistem telah dibangun dan seberapa bagus sistem telah dioperasikan.Siklus tersebut berlangsung secara berulang-ulang. Siklus di atas merupakan model klasik dari pengembangan sistem informasi. Model-model baru, seperti prototyping, spiral, 4GT dan kombinasi dikembangkan dari model klasik di atas.

\section{Karakteristik Sistem Informasi}

Karakteristik sistem informasi menurut (Al Fatta, 2007) yaitu batasan sistem (boundary), lingkungan (environments), masukkan sistem (input), keluaran sistem (output), komponen (component), penghubung (interface), penyimpanan (storage).

Untuk mendukung keputusan yang akan dilakukan oleh manajemen, maka manajemen membutuhkan informasi yang berguna. (Hartono M Jogiyanto, 1999) menyebutkan karakteristik informasi yang baik antara lain :

1. Kepadatan informasi artinya penjelasan yang disampaikan tidak terlalu panjamg lebar langsung pada inti penyampaian informasi (to do point).

2. Luas informasi artinya penggunaan informasi harus menyeluruh namun tidak terlalu lebar untuk penggunaan informasi.

3. Frekuensi informasi artinya jumlah penggunaan data dalam sistem informasiyang digunakan selalu dijaga sehingga tidak terlalu banyak informasi yang sama atau 
banyak.

4. Jadwal informasi artinya informasi harus selalu diperbaharui sehingga bersifat uptodate.

5. Waktu informasi artinya penjelasan kapan informasi itu dikeluarkan harus jelas.

6. Akses informasi artinya untuk mendapatkan informasi dapat didapat dengan mudah dan cepat.

7. Sumber informasi artinya informasi berasal dari pihak yang bisa dipertanggungjawabkan.

Penjelasan diatas merupakan dasar untuk pembuatan Sistem Inventarisasi Buku Perpustakaan Jurusan Teknik Elektro Universitas Negeri Semarang yang memiliki kriteria informasi baik dan sistem informasi yang baik. Sistem merupakan suatu bentuk integrasi antara satu komponen dengan komponen lain karena sistem memiliki sasaran yangn berbeda untuk setiap kasus yang terjadi di dalam sistem tersebut. Oleh karena itu sistem dapat diklasifikasikan dari beberapa sudut pandangan :

1. Sistem abstrak dan sistem fisik

- Sistem abstrakyaitu sistem yang berupa pemikiran atau ide-ide yang tidak tampak secara fisik. Contohnya sistem teologia, yaitu satu sistem yang berupa pemikiran tentang hubungan antara manusia dengan Tuhan.

- $\quad$ Sistem Fisik yaitu sistem yang ada secara fisik, contohnya sistem komputer, sistem produksi, sistem penjualan, sistem administrasi personalia, dsb.

2. Sistem alamiah dan sistem buatan manusia

- Sistem alamiahyaitu sistem yang terjadi melalui proses alam, tidak dibuat oleh manusia, contohnya sistem pemutaran bumi, terjadinya siang malam, pergantian musim.

- Sistem buatan manusia yaitu sistem yang melibatkan hubungan manusia dengan mesin, yang disebut denga Human machine Sistem. Contohnya sistem informasi berbasis komputer, karena menyangkut penggunaan komputer yang berinteraksi dengan manusia.

3. Sistem deterministik dan sistem probabilistik

- $\quad$ Sistem deterministik yaitu sistem yang beroperasi dengan tingkah laku yang dapat diprediksi. Contohnya sistem pemprograman dalam komputer, karena berdasarkan program2 komputer yang dijalankan.

- $\quad$ Sistem probabilistik yaitu sistem yang kondisi masa depannya tidak dapat diprediksi karena mengandung unsur probabilitas. Contohnya sistem pemilu, sistem pemerintahan.

4. Sistem terbuka dan sistem tertutup

- Sistem terbukayaitu sistem yang berhubuingan dan dipengaruhi oleh lingkungan luarnya, 
yang menerima masukan dan menghasilkan keluaran untuk sub sistem lainnya. Contohnya sistem perdagangan.

- Sistem tertutupyaitu sistem yang tidak berhubungan dan tidak dipengaruhi oleh lingkungan luarnya. Sistem ini bekerja secara otomatis tanpa ada campur tangan dari pihak luar. Contohnya sistem robotic, sistem arloji, ATM sistem.

Siklus hidup sistem yaitu proses evolusioner yang diikuti dalam penerapan sistem atau sub sistem informasi berbasis komputer. Siklus hidup sistem terdiri dari serangkaian tugas yang mengikuti langkah-langkah pendekatan sistem, karena tugas-tugas tersebut mengikuti pola yang teratur dan dilakukan secara topdown. Siklus hidup sistem sering disebut sebagai pendekatan air terjun (waterfall approach) bagi pembangunan dan pengembangan sistem. Pembangunan sistem hanyalah salah satu dari serangkaian dari daur hidup suatu sistem, meskipun demikian proses ini merupakan aspek yang sangat penting.

Fase/tahapan dari daur hidup suatu sistem :

a. Mengenali adanya kebutuhan

Sebelum segala sesuatunya terjadi, timbul suatu kebutuhan atau problema yang harus dapat dikenali sabagaimana adanya. Kebutuhan dapat terjadi sebagai hasil perkembangan organisasi. Volume kebutuhan itu meningkat melebihi kapasitas dari sistem yang ada. Semua kebutuhan ini harus dapat didefinisikan dengan jelas. Tanpa adanya kejelasan dari kebutuhan yang ada, pembangunan sistem akan kehilangan arah dan efektivitasnya.

b. Pembangunan sistem

Suatu proses atau serangkaian prosedur yang harus diikuti guna menganalisis kebutuhan yang timbul dan membangun sebuah sistem untuk memenuhi kebutuhan tersebut.

c. Pemasangan sistem

Setelah tahap pembangunan selesai, sistem kemudian akan dioperasikan. Pemasangan sistem merupakan tahap yang penting dalam daur hidup sistem, dimana peralihan dari tahap pembangunan menuju tahap operasional adalah pemasangan sistem yang merupakan langkah akhir dari suatu pembangunan sistem.

d. Pengoperasian sistem

Program - program komputer dan prosedur - prosedur pengoperasian yang membentuk suatu sistem informasi semuanya bersifat statis, sedangkan organisasi yang ditunjang oleh sistem informasi selalu mengalami perubahan karena pertumbuhan kegiatan, perubahan peraturan dan kebikjaksanaan ataupun kemajuan teknologi. Untuk mengatasi perubahan-perubahan tersebut, sistem harus diperbaiki atau diperbaharui.

e. Sistem menjadi usang 
Kadang - kadang perubahan yang terjadi begitu drastis sehingga tidak dapat diatasi hanya dengan melakukan perbaikan pada sistem yang sedang berjalan. Tiba saat dimana secara ekonomis dan teknis, sistem yang ada sudah tidak layak lagi untuk dioperasikan dan sistem yang baru perlu dibangun untuk menggantikannya.

\section{Komponen Sistem Informasi}

Sistem informasi terdiri dari komponen - komponen yang penting dan merupakan satu kesatuan. Jika komponen sistem informasi kurang, maka sistem informasi tersebut tidak dapat melakukan fungsinya yaitu pengolahan data dan tidak dapat mencapai tujjuannya, yaitu menghasilkan informasi yang relevan, tepat waktu dan akurat (Jogiyanto, 2003).

\section{Sistem Informasi BERBASIS CLIENT SERVER}

Pada dasarnya client server merupakan konsep arsitektur perangkat lunak atau software yang menghubungkan dua objek berupa sistem client dan sistem server yang saling berkomunikasi melalui jaringan komputer maupun satu komputer yang sama.

\section{Perancangan Sistem Informasi}

Perancangan sistem informasi adalah kombinasi antara perangkat lunak dan perangkat keras yang digunakan (Whitten et al., 2004). Kombinasi ini pada dasarnya perangkat lunak digunakan untuk merancang suatu aplikasi atau software dengan mengurutkan tranformasi masalah menjadi solusi.

Menurut (JOGIYANTO, 1999), perancangan sistem informasi mempunyai 2 tujuan yaitu :

1) untuk memenuhi kebutuhan para pemakai sistem,

2) untuk memberikan gambaran yang jelas kepada pemprogram komputer dan ahli - ahli teknik lainnya yang terlihat.

\section{Prinsip Dasar Perancangan Sistem}

Proses perancangan perangkat lunak merupakan kegiatan dan hasil yang menghubungkan dengan perangkatlunak, yang bertujuan untuk menghasilkan suatu produk perangkat lunak. Berikut adalah kegiatan dasar dalam proses perancangan perangkat lunak (Whitten et al., 2004) yaitu :

1.Penspesifikasian Perangkat Lunak 
Kegiatan ini dilakukan untuk menentukan fungsional dan operasional dari perangkat lunak.

2.Perancangan dan Pengiplementasian Perangkat Lunak Pembuatan perangkat lunak yang memenuhi persyaratan.

3.Validasi Perangkat Lunak

Perangkat lunak yang telah dibuat dilakukan proses validasi untuk menjamin bahwa perangkat telah berjalan sesusai dengan yang diinginkan.

4.Pengevolusian Perangkat Lunak

Perangkat lunak harus dapat dikembangkan untuk menghadapi kebutuhan yang sewaktu waktu berubah.

\section{Arti Penting Pengembangan Sistem}

(Rachmad Gesah Mukti prabowo, 2015) Pengembangan sistem (systems development) merupakan menyusun suatu sistem yang baru untuk menggantikan sistem yang lama secara keseluruhan atau memperbaikis istem yang telah ada. Sistem yang lama perlu diperbaiki atau diganti disebabkan karena beberapa hal, yaitu sebagai berikut ini:

1. Adanya permasalahan-permasalahan (problems) yang timbul di sistem yang lama.

2. Ketidakberesan dalam sistem yang lama menyebabkan sistem yang lama tidak dapat beroperasi sesuai dengan yang diharapkan.

3. Kecurangan-kecurangan disengaja yang menyebabkan tidak amannya harta kekayaan perusahaan dan kebenaran dari data menjadi kurang terjamin.

4. Kesalahan-kesalahan yang tidak disengaja yang juga dapat menyebabkan kebenaran dari data kurang terjamin.

5. Tidak efisiennya operasi.

6. Tidak ditaatinya kebijaksanaan manajemen yang telah ditetapkan.

\section{Metode Penelitian}

\section{Pendekatan Penelitian}

1. Pendekatan Terstukturk ; merupakan pendekatan yang memerlukan alat-alat (tools) dan teknik-teknik

2. Pendekatan sepotong melawan pendekatan system; merupakan pendekatan pengembangan system yang menekankan pada suatu kegiatan 
atau aplikasi tertentu saja

3. Pendekatan bawah-naik melawan pendekatan atas-turun;

merupakan pendekatan dari level bawah organisasi yaitu pendekatan mulai dari transaksi dan sampai ke strategi atau dari pendekatan strategi ke pendekatan transaksi

4. Pendekatan system menyeluruh lawan pendekatan moduler

5. Pendekatan lompatan jauh lawan pendekatan berkembang.

6. Pendekatan berorientasi objek

7. Pendekatan berbasis web

\section{Jenis Penelitian}

Dalam penelitian ini, jenis penelitian yang digunakan adalah penelitian deskriptif kuantitatif yaitu suatu penelitian yang menggunakan data kuantitatif yang terdapat dalam laporan keuangan dimana melalui teknik pengumpulan, pengolahan, penyederhanaan, penyajian dan analisis data, dan memberikan gambaran yang teratur tentang suatu peristiwa melalui observasi.

\section{Subyek Penelitian}

Subyek penelitian ini adalah Perusahaan Coffe Shop Songot, sedangkan yang menjadi obyek pada penelitian ini yaitu mengenai perancangan sistem informasi

\section{Jenis dan Sumber Data}

\section{a. Jenis data}

1. Data primer,

yaitu sumber data penelitian yang diperoleh langsung oleh peneliti (tidak melalui media perantara), data primer berupawawancara.

2. Data sekunder,

yaitu data yang diperoleh dalam bentuk yang sudah terjadi publikasi seperti, sejarah perusahaan, struktur organisasi, deskriptif jabatan, data-data perhitungan Pajak Pertambahan Nilai dan laporan laba rugi serta komponen yang ada pada perusahaan.

\section{Sumber data}

Data internal merupakan data penelitian yang berupa dokumen-dokumen akuntansi 
dan akuntansi yang dikumpulkan, dicatat dan disimpan didalam suatu organisasi. Dalam penelitian ini data intern dapat diperoleh dari perusahaan berupa laporan laba rugi.

\section{Instrumen Penelitian}

a. Studikepustakaan

Studi kepustakaan adalah pengumpulan data dengan membaca buku mencari literaturliteratur dan laporan-laporan yang berhubungan dengan penelitian.

Studi kepustakaan dilakukan dengan cara membaca literatur-literatur yang berhubungan dengan permasalahan yang sedang diteliti dan dapat dijadikan sebagai landasan teoritis bagi pembahasan masalah.

b. Metode interview (wawancara)

Metode wawancara adalah dialog yang dilakukan oleh pewawancara untuk memperoleh informasi dari terwawancara. (Suharsimi, 2002b)

Metode wawancara dilakukan dengan cara wawancara dengan pihak-pihak yang terkait dengan penelitian.

c. Dokumentasi

Dokumentasi adalah pengumpulan data yang bersumber pada benda-benda tertulis seperti buku-buku, majalah, peraturan, laporan, notulen rapat, dan catatan-catatan. (Suharsimi, 2002)Dokumentasi dilakukan dengan cara mencatat data-data akurat yang dibutuhkan pada penelitian ini dari tempat penelitian. Antara lain yaitu dokumentasi atas laporan laba rugi dan Coffe Shop Songot .

\section{Definisi operasional variabel}

Suatu system di dalam suatu organisasi yang mempertemukan kebutuhan pengolahan transaksi harian, mendukung opoerasi, bersifat manajerial dan kegiatan strategis dari suatu organisasi dan menyediakan pihak luar tertentu dengan laporan-laporan yang diperlukan

\section{Metode Analisis Data}

1. Mendefinisikan tujuan sistem (defining system goal), tidak hanya berdasarkan informasi pemakai, akan tetapi juga berupa telaah dari abstraksi dan karakteristik keseluruhan kebutuhan informasi sistem.

2. Mendefinisikan aktifitas pemrosesan data (defining data processing activities). Pendefinisian ini dapat dilakukan dengan pendekatan input-proses-output. Untuk 
menentukan hal ini diperlukan proses iteratif.

\section{Pembahasan}

\subsection{Analisis PIECES}

Untuk menganalisa sistem yang lama dimaksudkan untuk menemukan penyebab sebenarnya permasalahan-permasalahan yang terjadi sehingga sistem yang lama tidak berfungsi. Sistem yang lama akan diganti dengan sistem yang baru. Permasalahan-permasalahan di sistem yang lama perlu ditemukan dan diperbaiki. Jika sistem yang baru merupakan teknologi informasi maka perbaikan dari sistem yang lama berupa perbaikan-perbaikan dalam bentuk informasi yang disediakan oleh sistem yang baru. Supaya sistem yang baru berhasil, informasiinformasi yang dihasilkan harus sesuai dengan kebutuhan pemakainya. Menganalisis kebutuhan informasi pemakai perlu dilakukan untuk menghasilkan informasi yang relevan. Dengan dikembangkannya sistem yang baru, maka diharapkan akan terjadi peningkatanpeningkatan yang berhubungan dengan analisis PIECES (Performances, Informations, Economics, Control, Eficiency, and Service)

\section{Kinerja (Performances)}

Adalah kemampuan atau peningkatan terhadap kinerja (hasil kerja) sistem yang baru sehingga menjadi efektif. Kinerja dapat diukur dari Troughput dan Response Time. Troughput adalah jumlah pekerjaan yang dapat dilakukan suatu saat tertentu. Jadi ini berhubungan dengan seberapa maksimal pekerjaan yang dapat dilakukan oleh karyawan pada Coffee Shop SONGOT pada waktu tertentu dapat dikatakan efektif dan efisien. Response Time adalah rata-rata waktu yang tertunda diantara dua transaksi atau pekerjaan ditambah dengan waktu response untuk menanggapi pekerjaan tersebut.

Disini melihat seberapa lama waktu yang dibutuhkan atau waktu yang terbuang percuma oleh karyawan dalam melakukan pekerjaan atau dapat dikatakan efektifitas kerja karyawan.Hal ini bisa dilihat dari proses pengolahan data anggota misalnya pencarian data anggota serta pembuatan laporan yang dilakukan masih manual, sehingga dalam pengerjaannya memerlukan waktu yang lama yaitu sekitar 5 menit. 
Dengan adanya sistem yang baru ini, diharapkan kinerja karyawan menjadi maksimal yaitu sekitar 3 menit untuk menyelesaikan pekerjaan, sehingga pekerjaan dapat diselesaikan dengan cepat dan tepat waktu untuk tercapainya sasaran. Adapun perkiraan perbandingan sistem lama dengan baru adalah sebagai berikut:

\section{Tabel 3.2 Analisis Performance}

\begin{tabular}{|l|l|}
\hline Sistem Lama & Sistem Baru \\
\hline $\begin{array}{l}\text { Tugas-tugas dan beban } \\
\text { kerja karyawan lebih banyak }\end{array}$ & $\begin{array}{l}\text { Tugas dan beban kerja } \\
\text { karyawan lebih sedikit dan } \\
\text { lebih } \\
\text { Ringan }\end{array}$ \\
\hline
\end{tabular}

\section{Informasi (Informations)}

Informasi merupakan hal yang penting dan sangat menunjang bagi pimpinan dalam proses pengambilan keputusan. Laporan-laporan yang sudah selesai diproses mestinya digunakan untuk menghasilkan informasi yang dibutuhkan oleh manajemen maupun pihak lain yang membutuhkan. Dimana bagi pihak manajemen laporan tersebut dapat digunakan sebagai acuan untuk merencanakan langkah selanjutnya.

Dari analisis yang telah dilakukan terlihat bahwa pada Coffee Shop SONGOT masih terdapat beberapa situasi yang masih membutuhkan peningkatan kualitas kecepatan dalam pemberian informasi antara lain adalah laporan mengenai data anggota, data, dan data sirkulasi. Yang menjadi permasalahan dalam hal ini adalah kurang keakuratan data karena seringnya terjadi kesalahan dalam pencatatan data penjualan, data pengajian, serta presensi.

Dengan sistem yang baru ini mencoba membuat laporan menggunakan teknologi komputerisasi sehingga diharapkan dapat menghasilkan laporan sesuai dengan kebutuhan dan harapan serta dapat menghasilkan informasi yang terformat, akurat dan tepat waktu guna memberi manfaat bagi pemakai. Adapun perkiraan perbandingan sistem lama dengan sistem yang baru yaitu :

Tabel 3.3 Analisis Informations

\begin{tabular}{|l|l|}
\hline Sistem Lama & Sistem Baru \\
\hline
\end{tabular}




\begin{tabular}{|l|ll|}
\hline Informasi yang diperlukan misalnya data didapat & Informasi yang diperlukan lebih \\
dalam waktu yang cukup lama karena proses & cepat diperoleh yaitu dengan sistem \\
pencarian data masih membutuhkan arsip-arsip & searching data penjualan maka \\
yang ada. & informasi data dapat langsung \\
& diketahui.
\end{tabular}

\section{Ekonomi (Economics)}

Adalah penilaian sistem didalam penggunaan dana dan keuntungan yang didapat dari sistem yang dikembangkan. Nilai ekonomis merupakan motivasi paling umum bagi berjalannya suatu proyek. Persoalan ekonomi dan peluang berkaitan erat dengan biaya yang dikeluarkan oleh instansi/perusahaan.

Oleh karena itu untuk memperoleh keuntungan yang maksimal perlu adanya penghematan atas biaya yang dikeluarkan. Begitu juga dengan Coffee Shop SONGOT, penghematan dapat dilakukan melalui penggunaan sarana dan prasarana secara optimal.

Dengan menggunakan sistem lama terdapat pembengkakan biaya tinta alat tulis karena pencatatan data dilakukan secara manual dengan alat tulis, sehingga terjadi pemborosan. Diharapkan dengan adanya sistem yang baru nantinya akan memiliki nilai ekonomis yang akan mampu menghasilkan manfaat sesuai dengan biaya yang dikeluarkan dan pemborosan dapat diminimalkan.

\section{Tabel 3.4 Analisis Economic}

\begin{tabular}{|l|l|}
\hline Sistem Lama & Sistem Baru \\
\hline Pemborosan biaya dalam penggunaan kertas & Dengan sistem yang terkomputerisasi \\
dan alat-alat tulis yang digunakan untuk & akan menghemat waktu dan penggunaan \\
Penyimpanan dokumen, karena jika terjadi & kertas, alat tulis ataupun perlengkapan \\
kesalahan tidak dapat digunakan lagi dan data & penyimpanan dokumen jika terjadi \\
yang salah tidak dapat diedit. & kesalahan masih dapat diedit/diperbaiki. \\
\hline
\end{tabular}

\section{Kendali (Control)}

Digunakan untuk meningkatkan kinerja sistem, mendeteksi penyalahgunaan sistem dan menjamin keamanan data dari pihak luar yang tidak berkepentingan serta menjamin keamanan data informasi yang dihasilkan, semakin sedikit kesalahan yang dilakukan dalam suatu kegiatan, maka tingkat pengendalian suatu sistem semakin baik. 
Pada Coffee Shop SONGOT terlihat adanya pengendalian yang kurang maksimal, salah satu diantaranya adalah kurangnya pengendalian yang terdapat pada sistem informasi sirkulasi perpustakan sehingga data atau laporan yang dihasilkan kurang terjamin. Hal tersebut dikarenakan arsip dan dokumen penting terdiri atas beberapa laporan saja, tidak menyeluruh serta terdapat kesamaan data.

Dengan adanya pengawasan menggunakan sistem baru serta pengendalian yang dilakukan, diharapkan sistem akan lebih terkendali dan dapat berjalan dengan baik sesuai dengan standar yang diharapkan dan data lebih aman serta tidak terdapat kesamaan data.

\section{Efisiensi (Eficiency)}

Efisiensi berhubungan dengan bagaimana suatu sumber daya dapat digunkan dengan pemborosan minimal. Untuk meminimalkan sumber daya tersebut bisa dilakukan dengan cara menaikkan atau menurunkan komoditas berupa orang, uang, bahan atau sumber daya lainnya. Maksudnya adalah mendapatkan sebanyak-banyaknya dari yang sekecil-kecilnya atau paling tidak mendapatkan lebih banyak dari apa yang sudah ada.

Pada Coffee Shop SONGOT terlihat adanya ketidakefisienan dalam hal pengolahan data sirkulasi. Hal ini disebabkan sistem yang kurang baik, yang masih bersifat manual sehingga penggunaan sumber daya tenaga kerja lebih banyak karena beban kerja besar.

Dengan menggunakan sistem baru pengguanaa sumber tenaga kerja lebih sedikit, karena beban kerja ringan pengolahan data yang dilakukan dengan terkomputerisasi.

\section{Tabel 3.5 Analisis Eficiency}

\begin{tabular}{|l|l|}
\hline Sistem Lama & Sistem Baru \\
\hline Dengan beban kerja yang banyak maka & Dengan beban kerja yang sedikit maka \\
melibatkan banyak sumber daya & melibatkan sedikit sumbe Daya \\
\hline
\end{tabular}

\section{Pelayanan (Service)}

Peningkatan pelayanan yang lebih baik pada Coffee Shop SONGOT dimaksudkan untuk memberi kan pelayanan yang terbaik bagi pengunjung serta meningkatkan kepuasan kerja pegawai. Upaya peningkatan pelayanan tersebut dapat dilakukan melalui perbaikan dalam proses pengolahan data.Pada Coffee shop SONGOT terlihat bahwa konsumen harus 
menunggu lamanya antrian karena pencatatan data dilakukan secara manual dalam dokuman.

Dengan menggunakan sistem yang baru anggota tidak perlu mengantri lama- lama karena pelayanan lebih cepat dengan menggunakan sistem yang terkomputerisasi.

Tabel 3.6 Analisis Service

\begin{tabular}{|c|c|}
\hline Sistem Lama & Sistem Baru \\
\hline $\begin{array}{l}\text { Pelayanan informasi yang diperlukan } \\
\text { membutuhkan waktu yang lama }\end{array}$ & $\begin{array}{l}\text { Waktu yang dibutuhkan lebih } \\
\text { singkat } \\
\text { dan cepat }\end{array}$ \\
\hline
\end{tabular}

\section{Hasil Penelitian}

1. Perancangan Sistem

Perancangan sistem merupakan bagian awal dari pembuatan sistem informasi dimana tahapan ini bertujuan untuk memberikan ketentuan bentuk dan proses pada perangkat lunak yang dibuat agar pembuatan program tidak menyimpang dari aturan dan hasil analisis yang telah diterapkan pada perancangan program. Rancangan sistem secara umum juga merupakan gambaran secara umum yang ditunjukkan kepada user tentang sistem yang baru atau sistem yang diusulkan.

\begin{tabular}{|c|c|c|c|}
$\begin{array}{c}\text { Komputer } \\
\text { KASIR } \\
\text { ADMIN }\end{array}$ & Komputer \\
ABSEN
\end{tabular}

Arsitektur Komputer Yang Diusulkan 


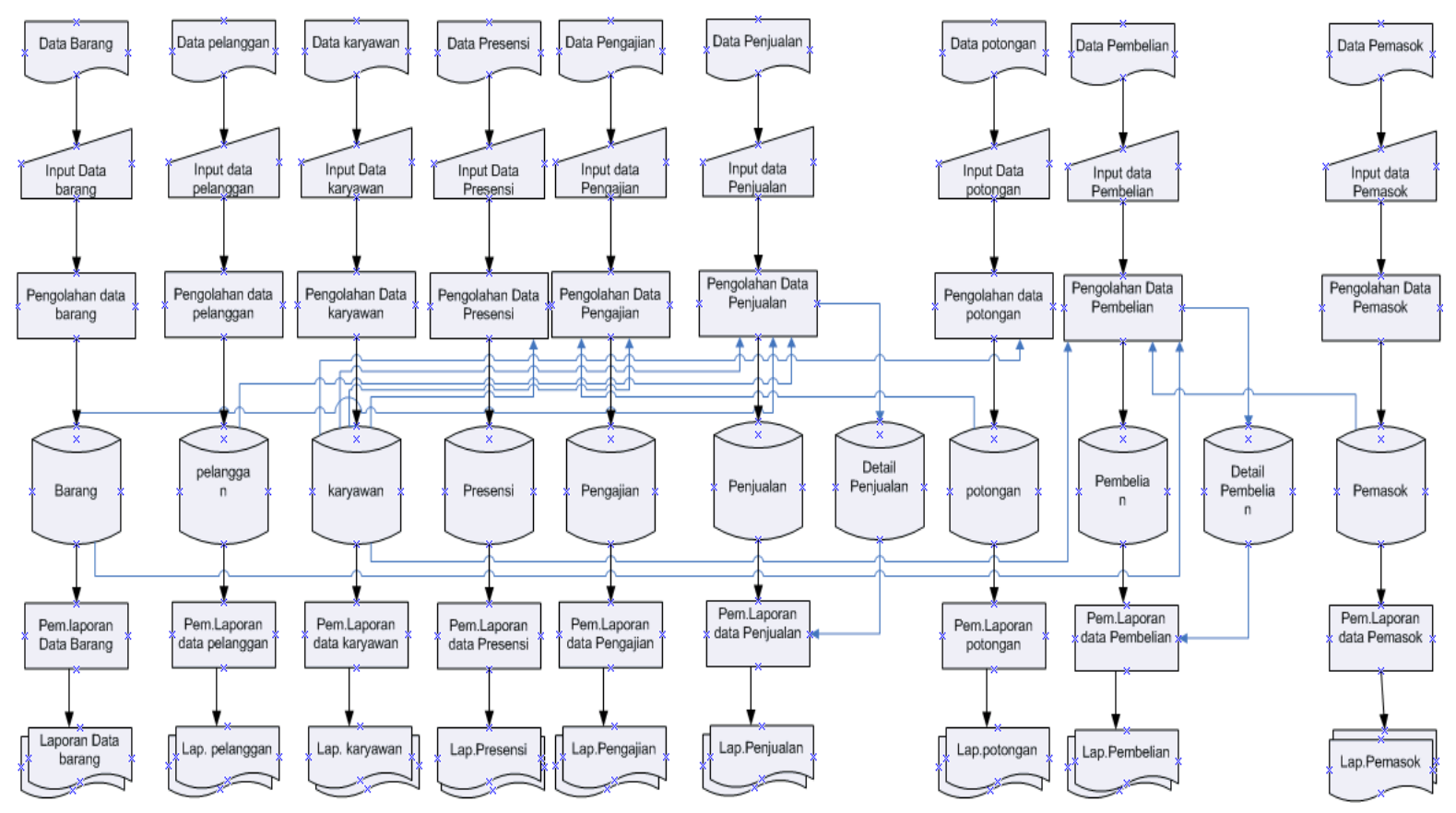

Flowchart Yang Diusulkan

\section{Kesimpulan}

Dari uraian dan penjelasan serta pembahasan keseluruhan materi pada bab-bab sebelumnya dan dalam mengakhiri pembahasan "ANALISIS DAN PERANCANGAN SISTEM INFORMASI PADA COFFEE SHOP SONGOT BERBASIS CLIENT SERVER”, maka penyusun mengambil kesimpulan bahwa :

Proses pengolahan data yang berjalan selama ini masih menggunakan cara manual, belum adanya program khusus untuk mengolah data mengakibatkan pelayanan informasi mengenai data penjualan, data absensi karyawan, data penggajian, masih kurang memuaskan dan menjadi sangat lambat. Misalnya saja kerumitan dalam pencarian data, kesalahankesalahan pencatatan data yang membutuhkan waktu perbaikan cukup lama, semua itu sangat perlu dibenahi. Oleh karena itu sistem manual saat ini perlu dikembangkan menjadi sistem 
yang terkomputerisasi.

Berdasarkan Kebutuhan Informasi, sistem dirancang meliputi Penjualan, absensi karyawan dan Penggajian. Dan disusun dengan beberapa table yang sudah melewati proses normalisasi. System nantinya akan menghasilkan beberapa laporan yang dibutuhkan diantaranya laporan penjualan, laporan karyawan, laporan pembelian dan laporan pelanggan \& pemasok.

Proses Implementasi sistem informasi yang baru berjalan dengan baik dilihat dari hasil pemrograman dan pengetesan program. Dan menunjukkan program berjalan dengan benar. Implementasi program meliputi Pemilihan dan Pelatihan Personil, Instalasi Perangkat Keras dan Perangkat Lunak, Pemrograman dan Pengetesan Program, Uji Coba Sistem dan Konversi Sistem.

Uji coba sistem dilakukan secara menyeluruh meliputi seluruh program- program sistem menggunakan tahap pengujian white box dan black box menunjukkan hasil yang baik dimana seluruh program-program dalam sistem sudah berjalan dengan normal dan baik.

Berdasarkan kesimpulan di atas, juga sebagai pertimbangan bagi pihak / pemilik Coffee Shop SONGOT di dalam usaha meningkatkan pelayanan dana kinerja Coffee Shop penyusun mempunyai beberapa saran yang dapat dipertimbangkan Adapun saran penyusun usulkan sebagai bahan pertimbangan untuk pihak Coffee Shop SONGOT guna untuk meningkatkan kualitas kerja yaitu :

Mengganti sistem yang masih manual menjadi sistem yang terkomputerisasi, dimana sistem terkomputerisasi dapat mengolah dan menyajikan data lebih efektif dan efisien dibandingkan dengan sistem manual.

Melakukan pertimbangan terhadap sistem yang penyusun usulkan dalam sistem tersebut dapat digunakan untuk proses pengolahan data.

Jika sistem yang penyusun usulkan ini digunakan oleh pihak Coffee Shop SONGOT, maka perlu diadakan pelatihan personil dalam menangani pengolahan data secara terkomputerisasi yang akan bertindak sabagai operator program, supaya proses penginputan data dapat berjalan dengan lancer dan sistem bekerja sesuai dengan harapan.

Dalam pembuatan aplikasi ini penyusun menyadari bahwa masih banyak kekurangan, baik dari segi penulisan, desain maupun dalam pembuatan aplikasi dikarenakan keterbatasan penyusun, untuk itu saran dan kritik sangat penyusun harapkan. Serta harapan penyusun semoga sistem ini dapat dimanfaatkan dengan sebaik-baiknya.

Demikian kesimpulan dan saran yang dapat penyusun sampaikan. Penyusun berharap sistem yang diusulkan ini dapat membantu dalam proses pencatatan data, pencarian data dan 
pengolahan data serta pembuatan laporan transaksi Coffee Shop. Sehingga dapat menghasilkan informasi dengan cepat dan akurat yang berguna dalam pengambilan keputusan bagi kemajuan Coffee Shop SONGOT.

\section{Daftar Pustaka}

Ackoff, R. L. (1971). Towards a system of systems concepts. Management Science, 17(11), $661-671$.

Al Fatta, H. (2007). Analisis dan Perancangan Sistem Informasi untuk keunggulan bersaing perusahaan dan organisasi modern. Penerbit Andi.

Fathansyah. (2015). Basis Data. Revisi Kedua. In Informatika, Bandung.

Hall, A. (1956). D. y FAGEN, R. E. “Definition of System”. General Systems, I, 18-29.

Jogiyanto. (2003). Analisis dan Desain Sistem Informasi. Andi offset.

JOGIYANTO. (1999). ANALISIS DAN SISTEM PERANCANGAN SISTEM INFORMASI.

Jogiyanto, H M. (2005). Analisis \& Desain Sistem Informasi. Yogjakarta: Andi Offset.

Jogiyanto, Hartono M. (1999). Pengenalan Komputer. Andi Offset, Yogyakarta.

Kadir, A. (2002). Pengenalan Sistem Informasi (Vol. Edisi 2). Yogyakarta: Andi Offset.

McLeod Jr, R. (2001). Sistem Informasi Edisi 7 Jilid 2. Prenhallindo. Jakarta.

Rachmad Gesah Mukti prabowo. (2015). Pengembangan sistem.

Romney, M. B., Steinbart, P. J., \& Cushing, B. E. (2000). Accounting information systems (Vol. 2). Prentice Hall Upper Saddle River, NJ.

Suharsimi. (2002a). Prosedur Penelitian. T Rineka Cipta. 
Suharsimi. (2002b). prosedur penelitian suatu pendekatan praktik.

Sutabri, T. (2012). Analisis sistem informasi. Penerbit Andi.

Sutarbi. (2005). sistem informasi managemen.

Watung, I. A., \& Sinsuw, A. A. E. (2014). PERANCANGAN SISTEM INFORMASI DATA ALUMNI FAKULTAS TEKNIK UNSRAT BERBASIS WEB. Jurnal Teknik Informatika. https://doi.org/10.35793/jti.3.1.2014.3922

Whitten, J. L., Dittman, K. C., \& Bentley, L. D. (2004). Metode design dan analisa sistem bibliografi. Yogyakarta, Andi Offset. 